\title{
Use of chitosan in the remediation of water from purification of biodiesel
}

\author{
Erivelton César Stroparo ${ }^{1 *}$, Krissina Camilla Mollinari ${ }^{1}$ and Kely Viviane de Souza ${ }^{1}$ \\ 'Laboratório de Qualidade de Águas, Departamento de Engenharia Ambiental, Universidade Estadual do \\ Centro Oeste - UNICENTRO, Irati, PR, Brasil \\ *stroparo.erivelton@gmail.com
}

\begin{abstract}
This article evaluates the efficiency of the degradation of pollutants present in water from the purification of biodiesel, characterized by high content of chemical oxygen demand (COD), suspended solids (SS), oils and greases, methanol, soap, and glycerol. The treatment process proposed was of the photo-Fenton type using iron immobilized in chitosan. The characterization of the material was performed according to degree of deacetylation (DD) and thermal stability (TG). The results revealed a DD of $66.5 \%$ and that the material undergoes decomposition in three temperature stages: 100; $150-350$ and above $350^{\circ} \mathrm{C}$. The evaluated parameters were: COD, suspended solids, oils and greases, color and turbidity. After a 180-minutes long treatment, the removal percentage was $94.52,70,55$, and $60 \%$ respectively. These results indicate that the photo-Fenton process can be an alternative for pre-treatment this type of effluent.
\end{abstract}

Keywords: biofuel, photo-degradation, transesterification, wastewater.

\section{Introduction}

The dependency on oil and the pollution generated by its extraction, benefiting, transportation, and burning, are the great disadvantages of the use of this fuel, a fact that has been encouraging the search for alternative energy sources, especially renewable ones. Biodiesel, because it is derived from oil seeds and even animal fat, present itself as a viable alternative to the total or partial substitution of diesel fuel. It can be obtained in different processes such as cracking, transesterification or esterification, resulting in glycerin as co-product ${ }^{[1]}$. However, in order to comply with international quality standards, biodiesel needs purification, which is carried out via washing.

The process aims at the removal of impurity and contaminants (catalyst, excess of alcohol, soaps, oils, and greases and residual glycerol) in excess, by the addition of great volumes of water, which results in wastewater with a high organic load, a fact that gives it low biodegradability ${ }^{[2]}$. Therefore, this wastewater is harmful to the environment and cannot be discharged into systems of collection and transportation of sanitation wastewater or bodies of water without a proper treatment $\mathrm{t}^{[3]}$.

There are several technologies that are employed in the treatment of this type of wastewater, including biological, chemical, and physical processes ${ }^{[4]}$. Researchers mention coagulation, electro-coagulation, biological processes and adsorption, in addition to the use of integrated processes, once the treatment of residual water has been one of the main concerns in terms of environmental protection. In addition to these, Advanced Oxidation Processes (AOPs) have been proposed as alternative technologies for isolated or combined treatment of wastewater of several classes, including the one generated during the purification of biodiesel ${ }^{[2-5]}$.
In comparison to other APOs, the homogeneous Fenton process has been widely studied to degrade several compounds and/or improve the biodegradability of aqueous effluents, and it is relatively cheap and easy to operate ${ }^{[5]}$. In this process, hydrogen peroxide $\left(\mathrm{H}_{2} \mathrm{O}_{2}\right)$ is catalyzed by ferrous ion $\left(\mathrm{Fe}^{2+}\right)$ in order to generate hydroxyl radicals $(\bullet \mathrm{OH})$, according to Equation 1.

$$
\mathrm{Fe}^{2+}+\mathrm{H}_{2} \mathrm{O}_{2} \rightarrow \mathrm{Fe}^{3+}+\cdot \mathrm{OH}+\mathrm{OH}^{-} \quad k_{1}=76 \mathrm{M} / \mathrm{s}
$$

Highly reactive and non-selective hydroxyl radicals may, on their turn, react with the substances of interest. $\mathrm{Fe}^{2+}$ ions can be regenerated through Equation 2, but the process is relatively slow ${ }^{[6]}$.

$$
\mathrm{Fe}^{3+}+\mathrm{H}_{2} \mathrm{O}_{2} \rightarrow \mathrm{Fe}^{2+}+\mathrm{HO}_{2} \cdot+\mathrm{H}^{+} \quad k_{2}=0.001-0.01 \mathrm{M} / \mathrm{s}
$$

In order to reinforce the regeneration of ferrous ions, light (UV or Vis) is usually introduced into the system. In the presence of irradiation, ferrous ions can be regenerated and additional hydroxyl radicals will be introduced via Equation 3.

$$
\mathrm{Fe}(\mathrm{OH})^{2+}+h v \rightarrow \mathrm{Fe}^{2+}+\cdot \mathrm{OH}
$$

Thus the efficiency of the process is enhanced, once that the catalytic cycle closes with the generation of 2 moles of hydroxyl radicals for each mole of initially decomposed $\mathrm{H}_{2} \mathrm{O}_{2}$.

In spite of its high oxidation efficiency, homogeneous Fenton process presents some major drawbacks: (i) the narrow $\mathrm{pH}$ interval, due to the fast precipitation of $\mathrm{Fe}(\mathrm{OH})_{3}$ with $\mathrm{pH}$ 
higher than 2.8 and, consequently an early termination of the reaction; (ii) the need to recover great amounts of iron sludge precipitating after the treatment; and (iii) the continuing of the treatment of the resulting sludge. Consequently, the global cost of the homogeneous photo-Fenton process is increased ${ }^{[6]}$. These factors limit the application of the homogeneous Fenton process, turning into an important drawback that restricts its use in great scale ${ }^{[7]}$. Therefore, efforts have been made to apply heterogeneous catalysts for the incorporation of iron species in several carriers, such as chitosan, for instance ${ }^{[5]}$.

Chitosan, an amino polysaccharide polymer, is obtained by alkaline deacetylation of chitin and is comprised of glucosamine (deacetylation units) and randomly distributed $\mathrm{N}$-acetyl-glucosamine units (acetylation units). It has been extensively used in fabric engineering and other biomedical applications because it is from natural origin, it is biodegradable, non-toxic, and bio-compatible, in addition to its susceptibility to chemical modifications ${ }^{[7]}$. These features make chitosan an interesting carrier for the immobilization of $\mathrm{Fe}^{2+} / \mathrm{Fe}^{3+}$ ions for later application in photo-Fenton-type processes, since its use for this end is not reported much.

Therefore, the present study aims at studying chitosan as a matrix for iron adsorption and its application in heterogeneous photo-Fenton process as a treatment for wastewater generated by biodiesel purification.

\section{Materials and Methods}

\section{1 Materials}

Chitosan with 100-mesh granulometry, purchased from Polymar, a company located in the state of Ceará, Brazil, was used without prior treatment. All chemical products possessed analytic degree and were used without any additional purification and the solutions were prepared using deionized water.

\subsection{Biodiesel production}

The conversion of soy oil into biodiesel was carried out via transesterification process in basic catalysis $(\mathrm{KOH} 3 \% \mathrm{~m} / \mathrm{v})$ and methyl route (methanol $30 \% \mathrm{v} / \mathrm{v})$. The oil was heated to $60{ }^{\circ} \mathrm{C}$, with $\mathrm{KOH}$ and methanol under stirring with a reactional time of 1 hour. The separation of biodiesel from its coproduct (glycerin) was carried out by decantation during 24 hours. Later, pure biodiesel (B100) was submitted to a purification process (washing) carried out in three stages, each one with the addition of a volume of water corresponding to that of biodiesel. The separation of the organic phase of the aqueous phase occurred by decantation.

\subsection{Preparation of chitosan spheres}

Chitosan spheres were prepared from $5.0 \mathrm{~g}$ of the polymer dissolved into $100 \mathrm{~mL}$ of a $5 \%$ acetic acid solution $(\mathrm{m} / \mathrm{v})$. Next, the polymer solution was trickled on an $\mathrm{NaOH} 2.0 \mathrm{~mol} \mathrm{~L}^{-1}$ solution. After the formation of the spheres, they were left in the $\mathrm{NaOH}$ solution for 24 hours in order to complete precipitation. Later, they were washed using water until wash water reached neutrality, Next, the spheres were submitted to a reticulation reaction with $0.1 \%(\mathrm{v} / \mathrm{v})$ glutaraldehyde during 24 hours and they were washed with water in order to remove excess of reticulating agent ${ }^{[8]}$.

For iron sorption, known amounts of reticulated spheres were added to a $250 \mathrm{~mL}$ of an $\mathrm{Fe}^{2+} 200 \mathrm{mg} \mathrm{L}^{-1}$ at $\mathrm{pH}=3$ solution, under orbital stirring (120 rpm). For determination re.

mnant $\mathrm{Fe}^{2+}$ in solution was used the Phenanthroline method (Fe B-3500 - Standard Methods for the examination of water and wastewater $)^{[9]}$.

\subsection{Determination of Deacetylation Degree $(D D)$ of chitosan}

The amount of amino protonated groups was determined for the chitosan sample with and without reticulation, through potentiometric titration. In his method, $0.2 \mathrm{~g}$ of chitosan was added to a $0.3 \mathrm{~mol} \mathrm{~L}^{-1} \mathrm{HCl}$ solution during 24 hours. Next, the solution was titrated with a $\mathrm{NaOH} 0.2 \mathrm{~mol} \mathrm{~L}^{-1}$ solution. The percentage of amino groups was calculated using Equation 4.

$$
\% N H 2=\frac{C N a O H \times(V 2-V 1) \times 161}{m}
$$

Where: $\mathrm{C}=$ concentration of the $\mathrm{NaOH}$ solution in mol $\mathrm{L}^{-1} ; \mathrm{V}_{1}$ and $\mathrm{V}_{2}$ the volumes used to neutralize the excess of $\mathrm{HCl}$ and to neutralize the sample of protonated chitosan, respectively; 161 corresponds to the value of molar mass of the monomeric unit of the chitosan; and $\mathrm{m}$ the mass of the sample $(\mathrm{g})$.

\subsection{Thermogravimetric Analysis (TGA)}

Thermal stability of the samples was evaluated via thermogravimetry, under an oxidation atmosphere employing a heating rate of $10{ }^{\circ} \mathrm{C} \mathrm{min}^{-1}$ (from room temperature up to $1000^{\circ} \mathrm{C}$ ).

\subsection{Treatment process}

Experiments were conducted in a $300 \mathrm{~mL}$ bench reactor equipped with water cooling, magnetic stirring system, and assisted by artificial radiation using a $125 \mathrm{~W}$ mercury vapor lamp inserted into the solution with the aid of a quartz bulb. $250 \mathrm{~mL}$ of biodiesel wash water was used in $\mathrm{pH}=7.3$ (which is natural of wash water); $200 \mathrm{mg} \mathrm{L}^{-1}$ of $\mathrm{H}_{2} \mathrm{O}_{2}$ and mass of spheres of $1 \mathrm{~g}$. Treatment time was 180 minutes.

\subsection{Analytical procedures}

The analyses were carried out in triplicate. The $\mathrm{pH}$ of the solutions was determined using a Phtek- PHS-3E meter. COD was measured using the closed reflux colorimetric method. $\mathrm{H}_{2} \mathrm{O}_{2}$ concentrations were spectrometrically determined using a modified methodology based on procedures described by literature ${ }^{[10]}$. Iron was evaluated using UV-vis spectroscopy, applying methodology based on complexation reaction between $\mathrm{Fe}^{2+}$ and o-phenanthroline. Determination of color, turbidity, SS, and oil and greases was carried out according to "Standard Methods" methodology ${ }^{[9]}$. 


\section{Results and Discussions}

\subsection{Determination of the degree of deacetylation of chitosan}

The degree of deacetylation is defined as the molar ratio of deacetylation in the $\mathrm{C}-2$ position of the 2-acetamido-2-deoxy-d-glucopyranose unit in polysaccharides chains. DD is one of the most important parameters for identifying the quality of chitosan, because it influences several physical-chemical properties of the material, such as solubility, flocculation, and ability of chelation with metallic ions ${ }^{[11]}$. The greater the amount of amino groups, the greater is electrostatic repulsion among chains and, consequently, greater is solvation in water. Arbitrarily, when the deacetylation degree is greater than $40 \%$ the polymer is defined as chitosan ${ }^{[12]}$.

Several methods have been described in the literature to determine DD, amongst them the most used are potentiometric titration ${ }^{[13]}$, UV spectroscopy ${ }^{[12]}$, infrared spectroscopy, mass spectroscopy ${ }^{[14]}$ and nuclear magnetic resonance spectroscopy[. However, the best method ${ }^{[15]}$ for

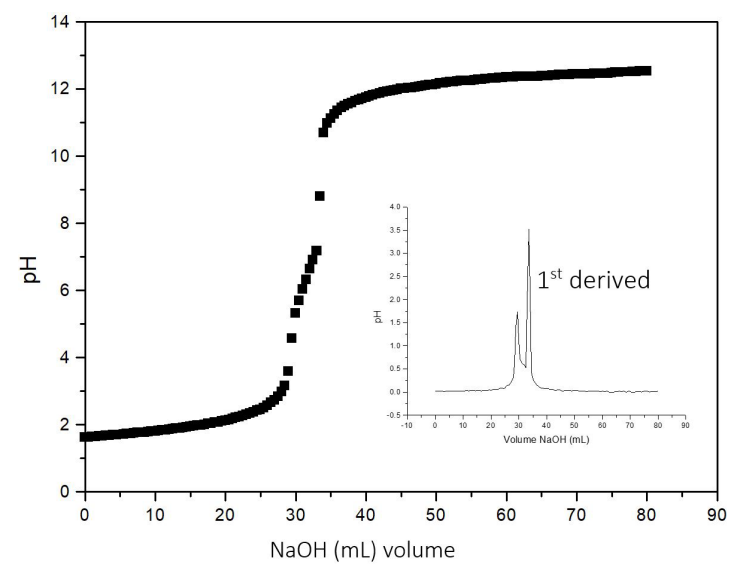

Figure 1. Curve of potentiometric titration of pure chitosan solution in $\mathrm{HCl}$. determining DD is still subject of studies. For these reasons, and taking into account the availability of equipment and ease of operation, potentiometric titration was the chosen method in this study. Figure 1 illustrates the profile of the curve obtained through potentiometric titration of the solution of pure chitosan.

It was possible to observe that the curve presents two inflexion points: the first is related to the neutralizing of excess of $\mathrm{HCl}$ in the solution and the second point refers to the neutralization of protonated amino groups ${ }^{[16]}$. The DD figure calculated using this method was $66.5 \%$.

For comparison ends, in the literature DD figures were found ranging from 50.0 to $92.3 \%^{[17-19]}$. These variations are due to the source and the way of obtaining the polymer developed by the manufacturer.

Reticulated spheres with glutaraldehyde do not present amounts of protonated amino groups that are measurable by the method. Only an inflexion in the potentiometric titration curve was observed, referring to the consumption of $\mathrm{NaOH}$ necessary to neutralize add $\mathrm{HCl}$, indicating the link of the glutaraldehyde by amino groups, as proposed in Figure 2. This behavior was also observed by Torres et al. ${ }^{[13]}$.

Taking into account and evaluating the two possibilities (reticulation and ramification), both may occur. However, after the reaction with glutaraldehyde, the spheres become insoluble in the acetic acid solution. Should only the formation of glutaraldehyde ramifications be favored, the resulting polymer would probably be more soluble than the precursor polymer, in the linear shape. Thus, it might be suggested that both processes have occurred, however the reticulation effect seems to be more effective.

\subsection{Thermal Gravimetric Analysis (TGA)}

Figures 3 and 4 show the results obtained from thermal gravimetric analyses for pure and reticulated chitosan spheres (before and after the insertion of iron), respectively.

The profile shown in Figure 3, referring to pure chitosan, reveals that the polymer suffers decomposition in three

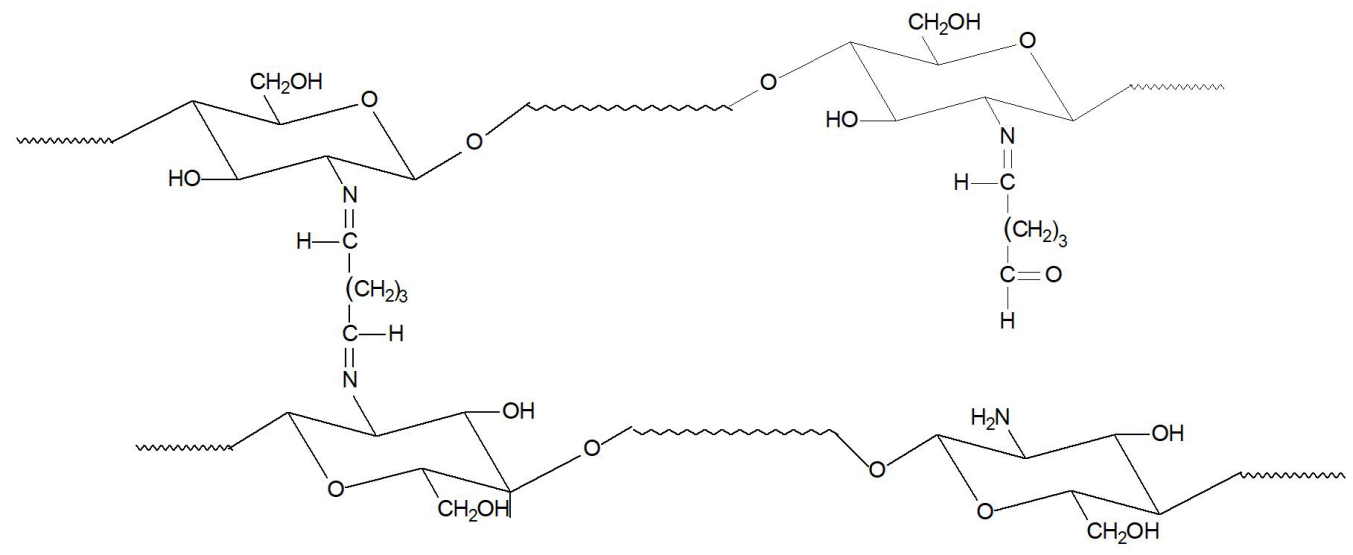

Reticulation

Ramification

Figure 2. Proposal of interaction of glutaraldehyde by the $-\mathrm{NH}_{2}$ chitosan group. 
temperature stages: the first, comprising temperatures below $100{ }^{\circ} \mathrm{C}$, is related to loss of water; in the second, between 150 and $350^{\circ} \mathrm{C}$, decomposition may be related to depolymerization of the material or to the deacetylation of acetamido groups from precursor chitin. The third stage, for temperatures above $350{ }^{\circ} \mathrm{C}$, may be attributed to the degradation of final residues of the biopolymer's organic matter.

The thermogram of reticulated chitosan (Figure 4A) also revealed three bands of loss of mass, differentiating only in the feature that reticulated chitosan presented less stability, considering that greater mass was lost in the second band, at lower temperature, of up to $230{ }^{\circ} \mathrm{C}$. The reticulation promoted by the reaction with glutaraldehyde should, in a first moment, promote an additional thermal stability to chitosan. This fact, however, was not observed when the data revealed by the thermograms was analyzed. This behavior may be justified due to the frailty of the imine $(-\mathrm{HC}=\mathrm{NH}-)$ links formed after the reticulation. Multiple links, whether they are shared among carbon atoms or among nitrogen and carbon, as it is the case in point, are thermolabile links, especially if the effect of the temperature is added to the effect

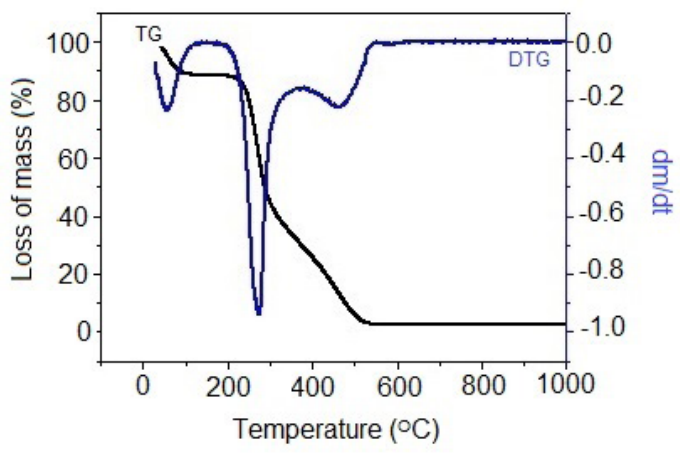

Figure 3. Thermogram obtained for the sample of chitosan without reticulation. of the oxidizing atmosphere. On the other hand, the thermal evaluation of the materials obtained after the insertion of iron in the structure of the polymer (Figure 4B) did not change the thermal profile of the reticulated chitosan, indicating that ion interactions did not change, neither favorably nor unfavorably, the behavior under the effect of the temperature of reticulated chitosan.

\subsection{Sorption of iron in chitosan spheres}

By monitoring $\mathrm{Fe}^{2+}$ concentration in solution, it was possible to calculate the adsorption capacity by the spheres, expressed by (qe), the amount of adsorbed iron in the balance, through Equation 5.

$$
q e=\frac{\left(C_{0}-C_{e q}\right) \times V}{m}
$$

Where: qe $=$ amount of $\mathrm{Fe}^{2+}$ sorbed $\left(\mathrm{mg} \mathrm{g}^{-1}\right)$; $\mathrm{Co}=$ initial concentration of iron $\left(\mathrm{mg} \mathrm{L}^{-1}\right)$; Ceq= concentration of iron in equilibrium $\left(\mathrm{mg} \mathrm{L}^{-1}\right) ; \mathrm{V}=$ volume of the $\mathrm{Fe}^{2+}$ solution used (L); $\mathrm{m}=$ mass of chitosan beads used in the sorption process $(\mathrm{g})$.

Figure 5 shows the adsorption capacity of chitosan spheres in function of time. It is possible to observe that balance was reached after 60 hours of contact. In this essay, a figure was obtained of approximately $36.0 \mathrm{mg}$ of adsorbed iron per gram of sample.

\subsection{Treatment of biodiesel wash water by photo-Fenton process}

The characteristics of biodiesel wash water have already been studied by several researchers and usually present high contents of COD, SS, oils, and grease ${ }^{[2]}$.

The characterization of water from biodiesel B100 purification is presented in Table 1 .

In regards to $\mathrm{pH}$, data from literature show that residual waters from biodiesel purification present $\mathrm{pH}$ values ranging from 3.14 to $11.00^{[20-22]}$. This wide range in $\mathrm{pH}$ value may

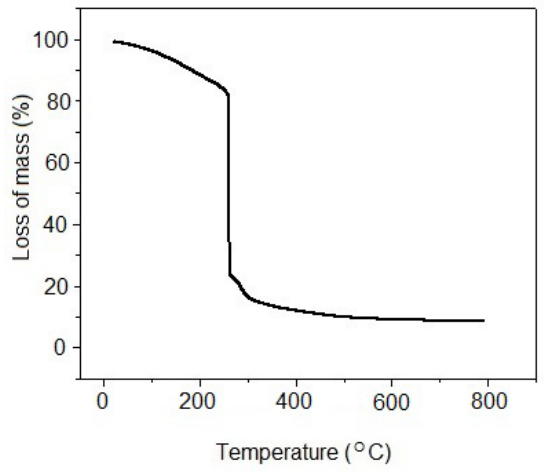

(A)

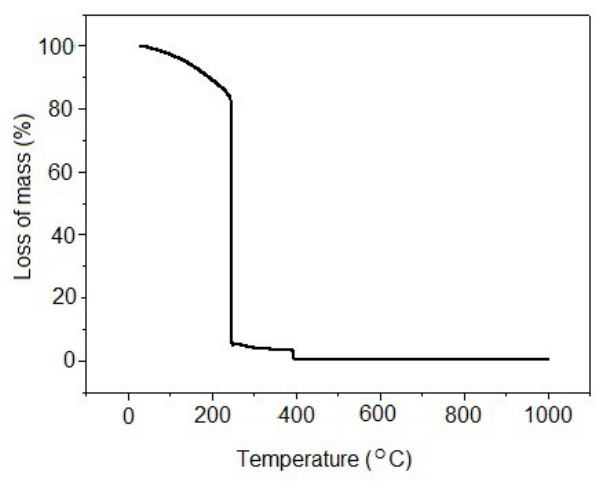

(B)

Figure 4. Thermogram obtained for the chitosan sample after reticulation by glutaraldehyde (A) and after insertion of iron (B). 


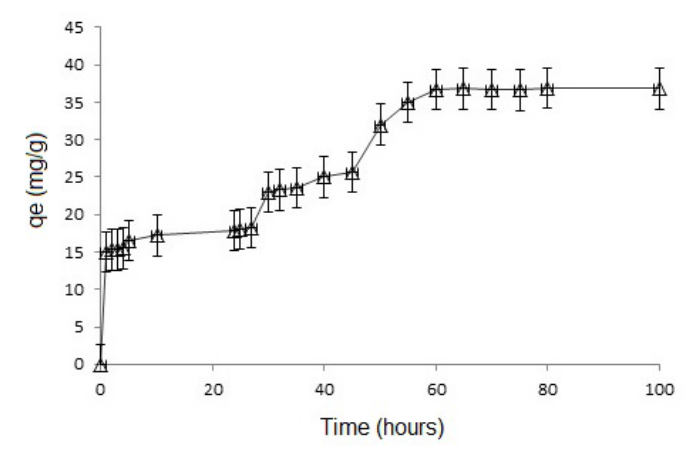

Figure 5. Representation of the concentration of ferrous ions sorbed by reticulated chitosan spheres.

Table 1. Characterization of water from biodiesel B100 purification.

\begin{tabular}{lcc}
\hline \multicolumn{1}{c}{ Parameter } & $\begin{array}{c}\text { Water } \\
\text { (Before treatment) }\end{array}$ & $\begin{array}{c}\text { Water } \\
\text { (After treatment) }\end{array}$ \\
\hline $\mathrm{pH}$ & 7.3 & 6.5 \\
$\mathrm{COD}\left(\mathrm{mg} \mathrm{L}^{-1}\right)$ & $5,556.0 \pm 0.9$ & $333.3 \pm 0.6$ \\
Turbidity (UNT) & $219.0 \pm 0.1$ & $87.6 \pm 0.1$ \\
$\mathrm{SS}\left(\mathrm{mg} \mathrm{L}^{-1}\right)$ & $243.4 \pm 2.3$ & $114.4 \pm 1.6$ \\
Oils and greases $\left(\mathrm{mg} \mathrm{L}^{-1}\right)$ & $730.5 \pm 1.7$ & $219.1 \pm 0.9$ \\
Color $(\mathrm{uC})$ & $1,450.1 \pm 0.3$ & $652.5 \pm 0.5$ \\
\hline
\end{tabular}

influence significantly conventional treatments of residual water, such as those physical-chemical, for instance. However, when using heterogeneous photo-Fenton process, $\mathrm{pH}$ does not influence the treatment, since the proposal was the use of immobilized $\mathrm{Fe}^{2+}$, thus it is possible to carry out the treatment without the need for adjustments in $\mathrm{pH}$ value, which is an advantage of the process.

The COD of the effluent is elevated, possibly due to the presence of oils and greases and, especially, of glycerol residue. In different works, researchers analyzedanalyzed the COD of the raw effluent generated from biodiesel purification, corresponding to $7,500 \mathrm{mg} \mathrm{L}^{-1}$ and $29,595 \mathrm{mg} \mathrm{L}^{-1}$ respectively ${ }^{[4,23]}$. The difference between the figures found in the literature in this study refers to the type of raw material adopted in the process and the route employed. An aquatic system that receives effluents presenting these levels of organic matter will result in the consumption of oxygen of the receiving body, and it might reach levels of total anoxia, depending on the type of bacteria in that environment, therefore the need is evident of treatment for this type of effluent.

With heterogeneous photo-Fenton process, after 180 minutes a $94 \%$ decrease of COD took place, however, since the initial figure was very high, this decrease was not enough for the final effluent to comply with discharge standards.

Regarding turbidity, it was observed to a $60 \%$ decrease, and the remaining turbidity might possibly be related to the presence of esters that form an emulsion that is difficult to remove. In spite of the fact that turbidity is not a direct indicator of risk to health, its increase in courses of water affects the light zone and, consequently, photosynthesis, interfering in the natural balance of that aquatic ecosystem. According to the EPA(Environmental Protection Agency), the quality of life within a mixing zone must be exempt of undesirable deposits and substances that produce changes in color, odor, and turbidity

For SS and oils and greases, the decrease was 53 and $70 \%$ respectively. The color of the treated effluent presented a $55 \%$ decrease, presenting a value that is above the maximum allowed ${ }^{[24]}$ this is probably due to the presence of residues from non-transesterified fatty acids.

The results obtained for the studied parameters indicate that the isolated photo-Fenton process is not enough for the treatment of this type of effluent; however, the combination with biological and/or physical-chemical processes might be a promising alternative. Ramírez and collaborators ${ }^{[25]}$ investigated the efficiency of an integrated process combining photo-Fenton with aerobic sequential batch reactor (SBR) for treatment of wastewater from an a biodiesel production plant. In this study, the homogeneous photo-Fenton process was applied, adjusting the $\mathrm{pH}$ of the wastewater to 2.3 and the treatment lasted 2 hours. The results express that the chemical oxidation process promoted a high potential of $\mathrm{CDO}$ removal, of approximately $90 \%$. However, some problems have been pointed out, such as the cost of UV radiation and the difficulty of decomposing the sludge formed at the end of the biological treatment ${ }^{[25]}$.

It should also be noted that $\mathrm{H}_{2} \mathrm{O}_{2}$ was monitored during the entire treatment process, and four additions of oxidizing agent were necessary, in a total of $800 \mathrm{mg} \mathrm{L}^{-1}$ over 180 minutes of treatment. Another important aspect to be taken into account is related to the chitosan matrix, which did not suffer decomposition during the treatment, a fact that was already expected, since the system is refrigerated and the temperature inside the reactor did not reach the temperature of material decomposition indicated by TGA analysis. Lastly, it was observed that iron was not released from the matrix into the solution, which suggests a possibility of reusing the spheres.

\section{Conclusions}

The production of biodiesel from soy oil results in a great amount of residual water with high levels of organic load, which needs to be treated efficiently in order to minimize its environmental impact. Several treatments are being studied for the treatment or pre-treatment of residual water from biodiesel and each one of them has both advantages and disadvantages.

This study has achieved the proposed goals, the chitosan matrix has revealed itself to be proper for its ability of $\mathrm{Fe}^{2+}$ ions sorption as well as stability in treatment conditions.

Isolated, photo-Fenton process did not present itself as being efficient. However, it might be indicated as pre-treatment for water from biodiesel purification, with a decrease of over $50 \%$, at least in the parameters that were analyzed, and it has the advantage of the possibility of application of heterogeneous photo-Fenton process in any $\mathrm{pH}$ range. 


\section{References}

1. Okoye, P. U., \& Hameed, B. H. (2015). Review on recent progress in catalytic carboxylation and acetylation of glycerol as a byproduct of biodiesel production. Renewable \& Sustainable Energy Reviews, 53, 558-574. http://dx.doi.org/10.1016/j. rser.2015.08.064.

2. Daud, N. M., Sheikh Abdullah, S. R., Abu Hasan, H., \& Yaakob, Z. (2015). Production of biodiesel and its wastewater treatment technologies: a review. Process Safety and Environmental Protection, 94, 487-508. http://dx.doi.org/10.1016/j.psep.2014.10.009.

3. Veljković, V. B., Stamenković, O. S., \& Tasić, M. B. (2014). Thewastewater treatment in the biodiesel production withalkalicatalyzed transesterification. Renewable \& Sustainable Energy Reviews, 32, 40-60. http://dx.doi.org/10.1016/j.rser.2014.01.007.

4. Pitakpoolsil, W., \& Hunsom, M. (2013). Adsorption of pollutants frombiodiesel wastewater using chitosan flakes. Journal of the Taiwan Institute of Chemical Engineers, 44(6), 963-971. http://dx.doi.org/10.1016/j.jtice.2013.02.009.

5. Gao, Y., Wang, Y., \& Zhang, H. (2015). Removal of Rhodamine $\mathrm{B}$ with $\mathrm{Fe}$-supported bentonite as heterogeneous photoFenton catalyst under visible irradiation. Applied Catalysis B: Environmental, 178, 29-36. http://dx.doi.org/10.1016/j. apcatb.2014.11.005.

6. Li, H., Li, Y., Xiang, L., Huang, Q., Qiu, J., Zhang, H., Sivaiah, M. V., Baron, F., Barrault, J., Petit, S., \& Valange, S. (2015). Heterogeneous photo-Fenton decoloration of Orange II over Al-pillared Fe-smectite: Response surface approach, degradation pathway, and toxicity evaluation. Journal of Hazardous Materials, 287, 32-41. http://dx.doi.org/10.1016/j. jhazmat.2015.01.023. PMid:25621831.

7. Barndõk, H., Blanco, L., Hermosilla, D., \& Blanco, A. (2016). Heterogeneous photo-Fenton processes using zero valent iron microspheres for the treatment of wastewaters contaminated with 1,4-dioxane. Chemical Engineering Journal, 284, 112121. http://dx.doi.org/10.1016/j.cej.2015.08.097.

8. Souza, K. V., Zamora, P. G. P., \& Zawadzki, S. F. (2010). Esferas de quitosana/Fe na degradação do corante Azul QR19 por processos foto-Fenton utilizando luz artificial ou solar. Polimeros: Ciência e Tecnologia, 20(3), 210-214. http://dx.doi. org/10.1590/S0104-14282010005000035.

9. Rice, E. W., Baird, R. B., Eaton, A. D., \& Clesceri, L. S. (2012). Standard methods for the examination of water and wastewater, 22nd ed. Washington: American Public Health Association, American Water Works Association, Water Environment Federation.

10. Oliveira, M. C., Nogueira, R. F. P., Gomes, J. A., No., Jardim, W. F. (2001). Sistema de injeção em fluxo espectrofotométrico para monitorar peróxido de hidrogênio em processo de fotodegradação por reação foto-Fenton. Química Nova, 24(2), 188-190. http://dx.doi.org/10.1590/S0100-40422001000200007.

11. Wang, C., Yuan, F., Pan, J., Jiao, S., Jin, L., \& Cai, H. (2014). A novel method for the determination of degree of deacetylation of chitosan by coulometric titration. International Journal of Biological Macromolecules, 70, 306-311. http://dx.doi. org/10.1016/j.ijbiomac.2014.07.007. PMid:25020083.

12. Tan, S. C., Khor, E., Tan, T. K., \& Wong, S. M. (1998). The degree of deacetylation of chitosan: advocating the first derivate UV- spectrophotometry meted of determination. Talanta, 45(4), 713-719. http://dx.doi.org/10.1016/S0039-9140(97)00288-9. PMid: 18967053.

13. Torres, M. A., Vieira, R. S., Beppu, M. M., \& Santana, C. C. (2005). Produção e caracterização de microesferas de quitosana modificadas quimicamente. Polímeros: Ciência e
Tecnologia, 15(4), 306-312. http://dx.doi.org/10.1590/S010414282005000400016 .

14. Duarte, M. L., Ferreira, M. C., Marvão, M. R., \& Rocha, J. (2001). Determination of the degree of acetylation of chitin materials by ${ }^{13} \mathrm{C} \mathrm{CP} / \mathrm{MAS}$ NMR spectroscopy. International Journal of Biological Macromolecules, 28(5), 359-363. http:// dx.doi.org/10.1016/S0141-8130(01)00134-9. PMid:11325422.

15. Lavertu, M., Xia, Z., Serreqi, N. A., Berrada, M., Rodrigues, A., Wang, D., Buschmann, M. D., \& Gupta, A. (2003). A validated $1 \mathrm{H}$ NMR method for the determination of the degree of deacetylation of chitosan. Journal of Pharmaceutical and Biomedical Analysis, 32(6), 1149-1158. http://dx.doi.org/10.1016/ S0731-7085(03)00155-9. PMid:12907258.

16. Jiang, X., Chen, L., \& Zhong, W. (2003). A new linear potentiometric titration method for the determination of deacetylation degree of chitosan. Carbohydrate Polymers, 54(4), 457-463. http://dx.doi.org/10.1016/j.carbpol.2003.05.004.

17. Jiang, D. S., Long, S. Y., Huang, J., Xiao, H. Y., \& Zhou, J. Y. (2005). Immobilization of Pycnoporus sanguineus laccase on magnetic chitosan microspheres. Biochemical Engineering Journal, 25(1), 15-23. http://dx.doi.org/10.1016/j.bej.2005.03.007.

18. Yang, Y. M., Wang, J. W., \& Tan, R. X. (2004). Immobilization of glucose oxidase on chitosan- $\mathrm{SiO}_{2}$ gel. Enzyme and Microbial Technology, 34(2), 126-131. http://dx.doi.org/10.1016/j. enzmictec.2003.09.007

19. Lin, H., Wang, H., Xue, C., \& Ye, M. (2002). Preparation of chitosan oligomers by immobilized papain. Enzyme and Microbial Technology, 31(5), 588-592. http://dx.doi.org/10.1016/ S0141-0229(02)00138-2.

20. Brito, J. F., Ferreira, L. O., Silva, J. P., \& Ramalho, T. C. (2012). Tratamento da água de purificação do biodiesel utilizando eletrofloculação. Quimica Nova, 35(4), 728-732. http://dx.doi. org/10.1590/S0100-40422012000400014.

21. Jaruwat, P., Kongjao, S., \& Hunsom, M. (2010). Management of biodiesel wastewater by the combined processes of chemical recovery and electrochemical treatment. Energy Conversion and Management, 51(3), 531-537. http://dx.doi.org/10.1016/j. enconman.2009.10.018.

22. Siles, J. A., Martin, M. A., Chica, A. F., \& Martin, A. (2010). Anaerobic co-digestion of glycerol and wastewater derived from biodiesel manufacturing. Bioresource Technology, 101(16), 6315-6321. http://dx.doi.org/10.1016/j.biortech.2010.03.042. PMid:20363620.

23. Grangeiro, R. V. T., Melo, M. A. R., Silva, E. V., Souza, A. G., \& Toscano, I. A. S. (2014). Caracterização física, química e toxicológica da água de lavagem gerada na produção de biodiesel. Revista Verde de Agroecologia e Desenvolvimento Sustentável, 9(1), 78-83. Retrieved in 2016, February 22, from https://www.gvaa.com.br/revista/index.php/RVADS/article/ view/2632

24. Sperling, M. V. (2014). Introdução à qualidade das águas e ao tratamento de esgotos. Belo Horizonte: Editora UFMG.

25. Ramírez, X. M. V., Mejía, G. M. H., López, K. V. P., Vásquez, G. R., \& Sepúlveda, J. M. M. (2012). Wastewater treatment from biodieselproduction via a coupled photo-Fenton aerobic sequentialbatch reactor (SBR) system. Water Science and Technology, 66(4), 824-830. http://dx.doi.org/10.2166/ wst.2012.250. PMid:22766873.

Received: Mar. 09, 2016

Revised: Sept. 12, 2017

Accepted: Dec. 22, 2017 